\title{
HIBAH SEBAGAI ALTERNATIF PEMBAGIAN HARTA PADA MASYARAKAT SUKU PATTAE (TELAAH ATAS HUKUM ISLAM)
}

\author{
Aminuddin \\ Usman Jafar \\ Supardin \\ Pascasarjana UIN Alauddin Makassar \\ Email: aminuddin.lahami@gmail.com
}

\begin{abstract}
Abstrak: Artikel ini membahas tentang "Hibah sebagai Alternatif Pembagian Harta pada Masyarakat Suku Pattae (Telaah atas Hukum Islam)." Jenis penelitian ini merupakan penelitian lapangan (field reseach) dengan jenis penelitian kualitatif deskriptif. Yaitu suatu jenis penelitian yang dimaksudkan untuk mengelola data yang terkumpul melalui wawancara terstruktur. Pendekatan analisis yang digunakan adalah descriptif analisis (analisis deskriptif). Sementara pendekatan penelitiannya adalah teologis normatif, yaitu suatu pendekatan yang mencoba memaparkan pemahaman dari sudut pandang hukum Islam untuk menjelaskan persoalan hibah orang tua sebagai alternatif pembagian harta. Hasil penelitian menunjukkan bahwa konsep hibah yang berlaku pada masyarakat suku Pattae dilakukan dengan cara berimbang, yaitu membagi rata tanah milik orang tua kepada seluruh anak yang ada melalui musyawara antara orang tua dan anak, baik ia anak laki-laki maupun anak perempuan. Namun perlu dicatat, bahwa harta milik orang tua yang telah diberikan kepada anak sewaktu-waktu bisa ditarik kembali oleh orang tua apabila terjadi sesuatu yang tidak diinginkan. Implikasi Penelitian; Keseimbangan antara hak dan kewajiban akan selalu hadir dari setiap keputusan yang bijaksana dan arif, tidak terkecuali dalam masalah pembagian harta. Al-Qur'an sebelum diturunkan di tanah Arab hak seorang perempuan dalam mendapatkan harta tidak dimungkinkan karena posisi dan derajat yang bangsa Arab anggap tidak ada nilainya. Namun setelah ke-Islam telah datang, maka hak seorang perempuan mulai tumbuh selayaknya hak seorang laki-laki pada umumnya. Islam tidak melihat hak seseorang dari sisi subjeknya tetapi melihat dari sisi kebutuhan dan tanggungjawabnya, maka setiap hak seorang laki-laki atau perempuan dalam mendapatkan harta haruslah berbanding lurus dengan kebutuhan dan tanggungjawab yang ia emban demi suatu keseimbangan dalam kehidupan yang lebih tentram.
\end{abstract}

Keywords: Hibah, Pembagian Harta, Suku Pattae, Hukum Islam

\section{Pendahuluan}


Banyaknya masyarakat Indonesia terus memperluas tanah yang mereka miliki, untuk dijadikan sebagai warisan kepada anak keturunannya demi kelangsungan hidup dimasa akan datang. Tradisi ini telah berjalan sejak lama bahkan sebelum masuknya agama Islam di Indonesia, pada saat itu mereka menggunakan hukum adat sebagai tolok ukur sah atau tidaknya pembagaian harta yang mereka lakukan. Harta merupakan salah satu benda berharga yang dimiliki manusia. Karena harta itu, manusia dapat memperoleh apapun yang dikehendakinya. Salah satu cara memperoleh harta itu adalah melalui jalur kewarisan yaitu memperoleh sejumlah harta yang diakibatkan dari meninggalnya seseorang. Tentunya cara ini pun harus sesuai dengan prosedur hukum yang berlaku.

Islam sebagai ajaran yang universal mengajarkan tentang segala aspek kehidupan manusia, termasuk dalam hal pembagaian harta. Islam mengajarkan tentang bagaimana pembagian harta dengan seadil-adilnya agar harta menjadi halal dan bermanfaat serta tidak menjadi malapetaka bagi keluarga yang ditinggalkannya. Sebab dalam kehidupan bermasyarakat, tidak sedikit terjadi perpecahan, pertikaian, dan pertumpahan dara akibat perebutan harta yang akan diwariskan kepada keturunan si mayit.

Berbagai problem dalam masyarakat tentang pembagian harta muncul dalam berbagai bentuk, misalnya kasus perebutan warisan Adi Firansyah misalnya, salah seorang artis yang tewas karena kecelakaan motor, akhirnya bergulir ke Pengadilan Agama Bekasi pada tanggal 12 April 2007, hartanya diperebutkan antara ibundanya dan istrinya Nielsa Lubis. ${ }^{1}$ Pada tanggal 28 September 2010, sebuah makam di Desa Buduran Sidoarjo Jawa Timur dibongkar guna mencocokkan DNA garis keturunan keluarga yang bersengketa warisan senilai 15 milyar. $^{2}$ Dan masih bayak kasus-kasus yang serupa dengan demikian.

Di samping itu, masyarakat Indonesia misalnya cenderung tidak ingin membedakan hak warisan laki-laki dan perempuan, pada hal dalam hukum Islam hak laki-laki dan perempuan dua banding satu ( $\left.\frac{1}{2}\right)$ telah dianggap final karena

landasan hukumnya qath'iy/pasti, baik dari segi kebenaran beritanya maupun dari segi petunjuknya, sehigga sangat sulit ditafsirkan lain. Bisa dilihat dalalam QS al-Nisa/4:11, 12 dan, 176 bahwa ayat ini sudah jelas dan sulit untuk ditapsirkan.

\footnotetext{
${ }^{1}$ Gossip, "Sidang Rebutan Warisan Adi Firansyah", Indosiar.com, 13 April 2007. http://www.Indosiar.com (05 Nopember 2016).

${ }^{2}$ Hukum dan Kriminal, "Rebutan Warisan, Sebuah Makam Terpaksa Dibongkar", Metrotvnews.com, 28 September 2010. htt://www.metrotvnews.com (05 Nopember 2016).
} 
Kalaupun ditafsirkan lain maka sangat sulit diterima oleh mayoritas masyarakat muslim pada umumnya. ${ }^{3}$

Salah seorang feminis muslim yang kritis terhadap persoalan waris dalam Islam adalah Amina Wadud. Ia adalah seorang Guru Besar Prongram Studi Agama di Virginia Commonwealth University (VCU) Amerika Serikat. Ia mengemukakan bahwa konsep pembagian warisan harus menekankan pada dua hal pokok, yaitu: kelompok perempuan, betapapun jauh hubungan kekeluargaannya harus mendapatkan bagian, semua pembagian warisan antara kerabat yang ada haruslah bersifat adil, dan keadilan bukan hanya soal nominalnya saja melainkan pada manfaat harta bagi orang yang ditinggalkan. Dengan memperhatikan manfaat harta bagi penerimanya ini, tentunya bagian laki-laki tidaklah harus selalu lebih besar dari yang diterima perempuan. ${ }^{4}$

Amina juga berkesimpulan bahwa, adanya kebebasan pembagian dari sepertiga harta tanpa memandang siapa dan golongan manapun dari ahli waris, dengan tidak mengurangi sisa pembagian dari bagian-bagian yang lainnya. Menurutnya, dengan cara berpikir demikian dan berdasarkan semangat pembagian warisan yang dijelaskan oleh al-Qur'an. Hukum waris sangatlah fleksibel, bisa berubah dan yang paling penting adalah dapat memenuhi rasa manfaat dan keadilan. ${ }^{5}$

Gencarnya arus feminisme tersebut, para pemikir muslim kontemporer kemudian menelaah kembali hukum Islam. Dari penelaahan tersebut akhirnya tersimpulkan bahwa yang salah bukanlah al-Qur'annya, akan tetapi penafsirannyalah yang keliru. Merekapun berusaha untuk menapsirkan ulang ayat-ayat al-Qur'an yang berkaitan dengan perempuan. Dari situlah kemudian, muncul berbagai macam produk penafsiran baru yang sangat beragam. Produkproduk tafsir baru ini memang rata-rata sangat emansipatoris, humanis dan populis. Namun sayangnya, penafsiran yang mereka lakukan sering kali tidak ditopang oleh metode dan kaidah penafsiran yang benar sebagaimana yang telah disepakati oleh para Ulama. ${ }^{6}$ Akibatnya mayoritas ummat muslim yang ada menolak akan pendapat tersebut dan tidak mau keluar dari konteks al-Qur'an yang bersifat murni.

Meskipun mayoritas ummat muslim enggan meninggalkan konteks alQur'an yang bersifat qath'iy/pasti tetapi mereka juga enggan meninggalkan

\footnotetext{
${ }^{3}$ Lihat, Abdul Gaffar, Hibah dalam Perspektif Hadis Nabi: Kajian Tematik Terhadap Alternatif Pembagian Harta (Makassar: Alauddin University Press, 2013), h. 2.

${ }^{4}$ Amina Wadud, Qur'an and Women: Rereading the Sacread Text from a Women's Perspective (New York; Oxford University Press, 1999), h. 114.

${ }^{5}$ Amina Wadud, Qur'an and Women: Rereading the Sacread Text from a Women's Perspective. h. 114.

${ }^{6}$ Abdurrahman bin Nashir As-Sa'di, Tafsir al-Karīmirrahmān (Damaskus: Dār al-Fikr, t.th.), h. 845 .
} 
kebiasaan-kebiasaan mayoritas muslim yang tumbuh dan hidup di masyarakat khususnya di Indonesia yang masih kokoh dalam memengang adat istiadat yang dianggap sebagai nilai-nilai leluhur yang telah dipertahan sejak nenek moyang mereka berada.

Begitupun dengan perbedaan agama di Indonesia yang tunduk kepada hukum adat dan perdata barat. Hukum tidak menjadikan perbedaan agama sebagai halangan untuk saling mewarisi, sebab antara muslim dan non-muslim dalam satu rumah itu merupakan sesuatu yang lumrah. Kondisi seperti ini bisa kita jumpai di wilayah Sulawesi-Selatan khususnya di bagian Tana Roraja. Sehingga apapun agamanya sepanjang dia memiliki hubungan kekerabatan maka ia tetap dijadikan sebagai ahli waris tanpa terkecuali. Berbeda dengan hukum kewarisan Islam yang selama ini diterapkan dilingkungan Peradilan Agama. Ahli waris non-muslim tidak akan mendapatkan warisan dari pewarisnya yang muslim atas dasar hadis. Demikian juga pasal 171 huruf b dan c KHI menyatakan bahwa pewaris dan ahli waris harus beragama Islam. ${ }^{7}$

Permasalahan lain yang terjadi di Indonesia khususnya di SulawesiSelatan dan Sulawesi-Barat berupa praktik adopsi anak yang masyhur dilakukan di kalangan masyarakat. Prinsip-prinsip ini mengatur; pertama, bahwa anak yang diadopsi secara otomatis dianggap dan dimasukkan ke dalam lingkungan keluarga yang mengadopsi. Kedua, bahwa hubungan anak yang diadopsi dengan orang tua biologisnya telah terputus dan. Ketiga, bahwa kedudukan anak yang diadopsi sama dengan kedudukan anak biologis. ${ }^{8}$

Hubungan penuh anak yang diadopsi dengan orang tua yang mengadopsi dan sebaliknya, menurut para ahli hukum, harus diluruskan karena hal itu bertentangan dengan al-Qur'an. Namun, para pembuat draf KHI merasa bahwa kebiasaan mewarisi satu sama lain harus dipertahankan, karena mereka juga menganggap bahwa tidaklah adil jika masing-masing pihak tidak ditinggali atau diberi bagian dari harta ketika pihak lainnya meninggal. Selain itu, para penyusun KHI juga menganggap bahwa sistem yang dipakai untuk bisa memberi dan menerima warisan di antara masing-masing pihak, baik si pihak yang mengangkat maupun yang diangkat tidak boleh dikaitkan dengan kedudukan kedua belah pihak sebagai anak atau orang tua yang sebenarnya. ${ }^{9}$

\footnotetext{
${ }^{7}$ Dede Ibin, Hibah: Fungsi dan Kolerasinya dengan Kewarisan (t.d.), h. 3.

${ }^{8}$ Hilman Hadikusuma, Hukum Waris Indonesia Menurut Perundangan, Hukum Adat, Hukum Agama Hindu dan Islam (Bandung: PT. Citra Adtya Bakti, 1991), h. 73.

${ }^{9}$ Asep Saepudin Jahar, dkk., Hukum Keluarga, Pidana dan Bisnis: Kajian PerundangUndangan Indonesia, Fikih dan Hukum Internasional (Jakarta: Kencana Prenada Media Grup, 2013), h. 89.
} 
Hukum Islam menolak lembaga anak angkat berdasarkan QS alAhzab/33: ayat 4, 5 dan $37 .{ }^{10}$ Dari tiga ayat tersebut menegaskan penolakan anak angkat dalam hal adopsi, yaitu masuknya anak angkat ke dalam lingkungan kerabatan orang tua angkatnya. Dengan demikian, tidak ada hubungan kewarisan antara orang tua angkat dengan anak angkatnya.

Selain adopsi anak, ada juga yang hangat diperbincangkan pada masa kini yaitu status anak di luar nikah (anak hasil perzinaan). Di Indonesia, masalah yang bisa menimpa para remaja dengan pergaulan bebas adalah kehamilan di luar nikah. Ketika kehamilan terjadi, bukan hanya pasangan kekasih yang merasa bingung dan malu, orang tua merekapun akan merasakan hal yang sama, dan bahkan lebih malu dari pasangan yang mengalami perbuatan itu sendiri.

Demi menghilangkan dan menyelesaikan permasalahan kehamilan di luar nikah atau akibat perzinaan, para orang tua biasanya menikahkan anak-anak mereka yang telah hamil tersebut baik dengan laki-laki yang menghamilinya ataupun dengan laki-laki yang bukan menghamilinya. ${ }^{11}$ Tetapi yang menjadi masalah selanjutnya, yaitu kaitannya dengan atatus anak dan hak-hak anak.

Seorang anak yang dilahirkan dari hasil perzinaan hanya dapat dinasabkan kepada ibunya dan tidak bisa dinasabkan kepada ayahnya. Akibatnya, beberapa hak anak yang seharusnya ia dapatkan dari ayahnya akan hilang. Ketentuan pandangan para Ulama dalam fikih tersebut didasarkan pada kesepakatan pandangan mereka bahwa sebab adanya nasab adalah adanya sebuah akad pernikahan, dan perzinaan tidak dapat menyebabkan tersambungnya nasab anak dengan ayahnya. ${ }^{12}$

Berbagai persoalan dan problemmatika yang dihadapi masyarakat Islam Indonesia kususnya di Sulawesi-Selatan dan Sulawesi Barat, baik yang terkait perebutan harta, penyamarataan warisan antara laki-laki dan perempuan, enggannya masyarakat meninggalkan nilai-nilai kebiasaan yang telah hidup di wilayah tempat tinggal mereka, hingga status hak waris anak angkat dan anak diluar pernikahan. Dari berbagai masalah ini, maka dibutuhkan sebuah alternatif penyelesaian, tanpa harus mengabaikan konteks ayat-ayat al-Qur'an dan hadis Rasulullah saw. yang berkaitan dengan persoalan pembagian harta dan tidak juga menimbulkan perdebatan di tengah-tengah masyarakat yang majemuk.

Suku Pattae merupakan masyarakat yang hidup di wilayah Kec. Binuang Kab. Polewali Mandar, Sulawesi Barat. Merupakan salah satu wilayah pertama

${ }^{10}$ Amir Syarifuddin, Hukum Kewarisan Islam (Jakarta: Kencana Prenada Media Group, 2012), h. 186.

${ }^{11}$ Asep Saepudin Jahar, dkk., Hukum Keluarga, Pidana dan Bisnis: Kajian PerundangUndangan Indonesia, Fikih dan Hukum Internasional, h. 50.

${ }^{12}$ Wahbah Zuhayly, Al-Fiqh al-Islāmiy wa Adillatuhu (Damaskus: Dār al-Fikr, 1984), h. 453-454; dikutip dalam Asep Saepudin Jahar, dkk., Hukum Keluarga, Pidana dan Bisnis: Kajian Perundang-Undangan Indonesia, Fikih dan Hukum Internasional, h. 58. 
yang didatangi oleh pembawa risalah ke Islaman di Sulawesi Barat yaitu syekh Kamaluddin sebelum yang termasyhur Imam Lappeo di Campalangiang. ${ }^{13}$

Menariknya dalam suku Pattae ini adalah metode pembagian harta orang tua yang menggunakan "Sistem Hibah" dengan mengedepankan musyawarah untuk kemudian menyamaratakan hak laki-laki dan perempuan yang merupakan nilai-nilai leluhur yang tumbuh di wilayah masyarakat Pattae tersebut, dengan tidak juga menyalahi konteks ayat-ayat al-Qur'an dan demikian juga halnya hadis Rasulullah saw. yang berkaitan dengan hibah.

\section{Tinjauan Umum tentang Pembagian Harta Orang Tua}

Pembagian harta orang tua pada dasarnya merupakan peralihan harta kepada keturunan dan kerabat-kerabat terdekatnya. Islam secara konseptual telah mengajarkan dan menetapkan tentang peralihan harta tersebut yang dituangkan dalam al-Qur'an dan hadist dengan secara terperinci, sehinga ummat Islam dapat menerapkannya dalam kehidupnya.

Harta benda merupakan aspek yang penting dalam kehidupan manusia. Tidak mungkin manusia terlepas dari aspek tersebut. Bahkan harta benda menjadi tolak ukur status sosial seseorang. Syariat Islam dalam ilmu kewarisan, zakat, infaq, shodaqoh, hibah, wakaf, dan wasiat merupakan instrumen Islam dalam pendistribusian harta kekayaan, karena ajaran Islam tidak mengizinkan terpusatnya harta kekayaan pada segelintir orang. Sehingga syariat Islam yang berkaitan dengan harta kekayaan seperti yang disebutkan, secara mantap juga meletakkan segi-segi sosial pada harta kekayaan yang ada pada manusia. ${ }^{14}$

Adapun konsep pembagian harta orang tua banyak disinggung dalam ilmu kewarisan, hibah dan wasiat yang secara penerapannya berbeda satu sama lain. Sekalipun demikian dalam pembagian harta orang tua khususnya kewarisan sangatlah bersifat kaku dan kontekstual, karena ketentuan hukumnya bersifat qath'iy sehingga peluang untuk menafsirkan tidak ada dan tinggal pelaksanaannya dilakukan.

Peralihan suatu harta orang tua dalam ilmu kewarisan pada dasarnya terjadi dengan sendirinya menurut ketentuan Allah swt. tanpa tergantung kepada kehendak dari pewaris atau permintaan dari ahli warisnya, sehingga tidak ada kekuasaan manusia yang dapat mengubahnya. Hal ini tercantum dalam QS AnNisa/4 ayat 11,12 , dan ayat 176 .

Konsep tersebut, dapat dilihat dalam asas ijbari di mana ketentuannya menyatakan bahwa harta akan secara otomatis atau berlaku dengan sendirinya

\footnotetext{
${ }^{13}$ Suradi Yasil, dkk., Naskah Awal Sejarah Polewali Mandar (Polewali Mandar: Pemeriantah Kab. Polewali Mandar-Dinas Perhubungan dan Informatika, t.th.), h. 63-64.

${ }^{14}$ Ali Yafie, Menggagas Fiqih Sosial: Dari Lingkungan Hidup, Asuransi, Hingga Ukhuwah (Cet. III; Bandung: Mizan, 1994), h. 23.
} 
kepada ahli warisnya menurut ketetapan Allah tanpa ditentukan kehendak ahli waris atau pewaris. Ahli waris langsung menerima kenyataan pindahnya harta si meninggal dunia kepadanya, sesuai dengan jumlah yang telah di tentukan. ${ }^{15}$

Dari pemaparaan tesebut, maka perlu dijelaskan tiap-tiap pengertian tentang apa itu kewarisan, hibah, wasiat, agar dapat mengklarifikasikan atau membedakan satu sama lain, sehingga memudahkan dalam memahami suatu pembahasan. Adapun pengerian yang dimaksud sebagai berikut:

\section{Kewarisan}

Secara umum kewarisan merupakan peralihan harta benda atau harta kekayaan berupa tirkah dari pewaris kepada ahli waris dengan mengikuti aturan hukum yang berlaku. ${ }^{16}$ Kata warisan sendiri merupakan sesuatu yang diwariskan, seperti harta dan nama baik, ${ }^{17}$ kata warisan diambil dari bahasa Arab dengan dasar kata waris yang secara etimologi merupakan bentuk isim fa'il dari kata waritsa, yaritsu, irtsan, fahuwa waritsun yang bermakna orang yang menerima warisan. ${ }^{18}$ Adapun yang menggunakan nama warisan memandang kepada harta pewaris yang menjadi objek dari hukum ini. ${ }^{19}$

Di dalam istilah hukum yang baku digunakan kata kewarisan, dengan mengambil kata waris dengan dibumbuhi awalan "ke" dan akhiran "an". Kata waris itu sendiri dapat berarti orang, pewaris sebagai sabjek dan dapat berarti pula proses. Dalam arti yang pertama mengandung makna hal ihwal orang yang menerima warisan dan dalam arti yang kedua mengandung makna hal ihwal peralihan harta yang sudah mati kepada yang masih hidup dan dinyatakan berhak menurut hukum yang diyakini dan diakui berlaku serta mengikat untuk semua yang beragama Islam. ${ }^{20}$ Sedangkan warisan dalam KUH Perdata disebutkan hukum waris ialah perpindahan dari sebuah harta kekayaan yaitu merupakan keseluruhan hak-hak dan kewajiban-kewajiban dari orang yang mewariskan kepada para warisnya. ${ }^{21}$ menurut Abū al-Husain Ahmad bin Fāris bin Zakariyyā

${ }^{15}$ Lihat, Abdul Wahid dan Muhibbin, Hukum Kewarisan Islam (Jakarta: Sinar Grafika, 2009), h. 23.

${ }^{16}$ Supardin, Fikih Peradilan Agama di Indonesia: Rekonstruksi Materi Perkara Tertentu (Cet. I; Makassar, Alauddin University Press, 2014), h. 129.

${ }^{17}$ Kementerian Pendidikan Nasional, Kamus Besar Bahasa Indonesia, Edisi III, (t.d). h. 1269.

${ }^{18}$ Hasbiyallah, Belajar Mudah Ilmu Waris (Bandung: PT. Remaja Rosdakarya, 2007), h. 1.

${ }^{19}$ Aulia Muthiah dan Novy Sri Pratiwi Hardani, Hukum Waris Islam: Cara Mudah dan Praktis Memahami dan Menghitung Warisan (Jakarta: PT. Buku Seru, 2015), h. 15.

${ }^{20}$ Moh. Muhibbin dan Abdul Wahid, Hukum Kewarisan Islam: Sebagai Pembaharuan Hukum Positif di Indonesia (Jakarta: Sinar Grafika 2011), h. 9.

${ }^{21}$ G. Kartasapoetra R. G. Kartasapoetra, Pembahasna Hukum Benda Hipotek Hukum Waris (Cet. I; Jakarta: Bumi Aksara, 1990), h. 83. 
warisan ialah sesuatu yang menjadi milik seseorang atau kelompok kemudian menjadi milik orang lain karena keturunan atau sebab yang lain. ${ }^{22}$

2. Hibah

Hibah merupakan sebuah bahasa serapan dari bahasa Arab yang kemudian diformalkan ke dalam bahasa Indonesia. Hibah dalam Kamus Besar Indonesia diartikan sebagai pemberian dengan sukarela dengan mengalihkan hak atas sesuatu kepada orang lain. ${ }^{23}$ Sedangkan dalam bahasa Arab, hibah merupakan bentuk isim masdar dari kata هو و yang artinya adalah pemberian yang sepi dari imbalan. ${ }^{24}$ Al-Jurjani mengatakan bahwa hibah secara etimologi adalah altabarru'sedekah atau derma, sedangkan secara termenologi adalah memilikkan suatu materi tanpa ada unsur imbalan. ${ }^{25}$ Kemudian;

3. Wasiat

Wasiat pada dasarnya dari kata bahasa Arab al-washiyah (jamaknya washaya), secara harfiah antara lain berarti: pesan, perintah dan nasihat. Ulama fiqih mendefinisikan wasiat dengan: "Penyerahan harta secara sukarela dari seorang kepada pihak lain yang berlaku setelah orang tersebut wafat, baik harta itu berbentuk materi maupun berbentuk manfaat". ${ }^{26}$

Orang yang berwasiat dinamakan al-mushi atau al-muwashshi, sedangkan orang (pihak) yang mengurus/diserahi atau pelaksana wasiat disebut al-washiy (jamaknya awshiya), dan sesuatu yang diwasiatkan oleh washi dinamakan almusha bihi. Adapun orang (pihak) yang menerima wasiat disebut sebagai almusha lah, atau al-musha ilayh. ${ }^{27}$

Disyaratkan bagi orang yang memberi wasiat ialah orang yang ahli kebajikan, yakni orang yang cakap melakukan perbuatan hukum. Kemudian bagi orang yang menerima wasiat, yakni dia bukanlah ahli waris dari yang memberi wasiat; orang yang diberi wasiat ada pada saat pemberi wasiat mati, baik ada secara benar-benar ataupun ada secara perkiraan; serta penerima wasiat tidak membunuh orang yang diberi wasiat. ${ }^{28}$

${ }^{22}$ Abū al-Husain Ahmad ibn Fāris ibn Zakariyā, Mu'jam Maqāyīs al-Lugah, Juz IV (Bāirut: Dār al-Fikr, 1423 H./ 2002 M.), h. 79.

${ }^{23}$ Tim Penyusun Kamus Pusat Bahasa, Kamus Bahasa Indonesia, Edisi III, h. 398.

${ }^{24}$ Muhammad bin Mukrim bin Manzhūr al-Afrīịi, Lisān al- 'Arab, Juz I (Cet. I; Bāirut: Dār Shadir, t.th.), h. 803.

${ }^{25}$ Ali bin Muhammad bin 'Ali al-Jurjānī, al-Ta'rīifat (Cet. I; Bāirut: Dār al-Kitāo al'Arabi, 1405 H.), h. 319.

${ }^{26}$ Tim Penyusun, Ensiklopedi Hukum Islam (Cet. V; Jakarta: Ichtiar Baru-Van Hoeve, 1997), h. 1926.

${ }^{27}$ Muhammad Amin Suma, Hukum Keluarga Islam di Dunia Islam (Cet. I; Jakarta: PT. Raja Garafindo Persada, 2004) h. 128.

${ }^{28}$ Lihat, Abd. Shomad, Hukum Islam: Penormaan Prinsip Syariah dalam Hukum Idonesia (Cet. II; Jakarta: Kharisma Putra Utama, 2010), h. 340. 


\section{Gambaran Umum Suku Pattae}

"Pengembara yang melintas jauh dari pesisir, jejak setapak sunyi di lembah yang mencekam, langit hitam membendung air para mahluk yang dahaga, inilah bate pallosa-losa padang nenek moyang parang suku Pattae.

"Suku Pattae" bisa juga disebut "To-Pattae" merupakan suatu suku yang menurut ahli sejarawan kerajaan Binuang Tengguru Matta, beliau berpendapat bahwa; kata To-Pattae secara etimologi terdiri dari tiga makna kata yaitu "To, Pat, dan Tae". "To" berarti orang, "Pat" berarti gelar tertinggi, dan "Tae" berarti rumpun, yaitu rumpun Tae dengan bahasa khas tersendiri yang mendiami wilayah Sulawesi-Selbar melingkupi; Polewali Mandar, Pinderang, Enrekang, Palopo, Luwu, Toraja, Makale, Mamasa, dan Mamuju. Sedangkan secara terminologi "To-Pattae" iyalah; orang atau manusia yang bergelar tinggi yang masuk dalam rumpun Tae dengan adat istiadat tersendiri yang mendiami wilaya kerajaan Binuang yang terletak di Kab. Polewali Mandar bagian Selatan berbatasan dengan Kab. Pinderang. ${ }^{29}$

To-Pattae atau suku Pattae cukup di kenal di daerah Sulawesi Barat khususnya di Kab. Polewali Mandar, sebab suku ini cukup memiliki pengaruh dalam berngai sektor pemerintahan. Rektor Universitas Negeri Makassar (UNM) Priode 2015-2019 misalnya, yang diduduki oleh Prof. Dr. H. Husain Syam, M.Tp. yang merupakan keturunan langsung dari suku Pattae, begitupun dengan Kanwil Kementerian Agama Provinsi Sulawesi Barat tahun 2014 sampai sekarang (2018) yang dipengang oleh H. Muhdi, S.Ag. M.Pd.I. yang tidak lain juga merupakan suku Pattae dan masih bayak lagi yang tidak bisa disebutkan satu persatu, akan posisi dan jabatan penting yang duduki di negeri ini.

Nenek moyang To-Pattae merupakan orang yang berasal dari Tomakaka Batu Tambuli, yaitu berupa batu besar dengan diameter kurang lebih 100x100 m. persegi dengan posisi berdiri tegak di puncak buttu Pamutu (gunung Pamutu) yang darinya awal tetesan air pertama sungai Binuang yang mengalir hingga kepenghulu muara kerajaan Binuang. Sungai Binuang juga merupakan sungai berarus deras sebagai sumber pasokan utama air persawahan dan perkebunan. Sungai ini dalam sejarahnya telah membelah dua wilayah kekuasaan Tomakaka yaitu wilayah kekuasaan Tomakaka Biru dan Tomakaka Penaniang yang merupakan dua kelompok masyarakat yang selalu bersaing diberbagai sudut kewibawahan kerajaan.

Sejarah awal mula suku ini dengan melihat dari sudut pandang cerita rakyat yaitu; ketika para pesuruh Tomakaka Batu Tambuli menemukan seorang wanita ditengah-tengah hutan yang pada saat itu, ia sedang berburuan binatang

\footnotetext{
${ }^{29}$ Matta (71 Tahun), Tokoh Adat Batetangnga, Wawancara, Batetangnga, 04 Desember 2017.
} 
liar. Sontak mereka langsung melapor kepada Tomakaka bahwa ia melihat seseorang di tengah-tengah hutan, dengan perasaan yang terkejut Tomakaka langsung bergegas untuk menemuinya.

Sesampainya Tomakaka pada wanita itu, ia langsung menyapanya; "Siapa anda sebenarnya?" Wanita ini menjawab, “aku adalah Tomillajang!" (melayanglayang/menghilag-hilang). Karena Tomakaka ini tidak memiliki istri maka ia berniat untuk menikahinya. Namun Tomillajang memberikan persyaratan dengan sumpah. Persyaratan tersebut berupa larangan untuk mencaci atau mencerca Tomillajang selama ia bersama kelak dan termasuk ke keturunan-keturunannya.

Setelah Tomakaka menerima persyaratan tersebut, maka terjadilah pernikanhan diantara mereka. Hari-hari keduanya dipenuhi dengan kebahagiaan dan kebahagiaan itu ditamba, ketika lahirnya seorang anak perempuan dari pasangan ini. Tidak berselang lama ketika Tomakaka datang berburuh binatang dan ia sangat kelelahan. Lalu ia menyandarkan tubuhnya di salah satu tiang gubuknya tiba-tiba beberapa serbuk kayu yang berasal dari selah-selah alas papan atas menjatuhinya dan memasuki kedua matanya, sontak ia langsung membentak dan mengeluarkan kata-kata cacian yang pelakunya bukan lain adak perempuanya sendiri.

Tidak sadar atas sumpah yang ia janjikan, tiba-tiba tertiuplah angin kencang dan Tomillajang yang tidak lain istrinya sendiri kemudian pergi menjauh darinya. Menyadari akan perbuatannya, Tomakaka berdiri kemudian mengejar Tomillajang hingga jauh dari wilayah yang ia kenal, namun ia tidak kunjung menemukan istrinya tersebut. Lelah dan putus asah, Tomakaka kemudian memutuskan mengakhiri akan usaha pencariannya dan kembali ke 'buttu Paputu' (gunung Pamutu). ${ }^{30}$

Suku Pattae umumnya mendiami Kec. Binuang sebuah Kecamatan di Kabupaten Polewali Mandar, Sulawesi Barat, Indonesia. Dulunya daerah ini berdiri sebuah kerajaan yang bernama Kerajaan Binuang (Kerajaan suku Pattae) yang diambil dari nama kayu binuang yang tumbuh di sepanjang pesisir sungai Binuang. Kayu Binuang ini digunakan untuk membangun rumah sang raja yang disebut Salassa. Pungsi Salassa sendiri sama halnya dengan rumah-rumah raja pada umumnya, seperti di kerajaan Gowa disebut Balla Lompoa, sedangka di kerajaan Yogyakarta disebut dengan Keraton, yang semuanya berpungsi sebagai pusat aktifitas kerajaan.

Penduduk di Kecamatan Binuang mayoritas suku Pattae, selebihnya suku Mandar, suku Bugis, dan suku Pattinjo. Luas Kecamatan Binuang adalah 123,34 km. persegi, dengan geografi terdiri dari pulau-pulau, daratan pesisi dan

${ }^{30}$ Hasan Dalle (72 Tahun), Tokoh Adat Batetangnga, Wawancara, Batetangnga, 15 Desember 2017. 
pegunungan. Batas-batas Kecamatan Binuang, antara lain: sebelah utara berbatasan dengan Kecamatan Anreapi, sebelah timur berbatasan dengan Kabupaten Pinrang, sebelah barat berbatasan dengan Kecamatan Polewali dan sebelah selatan berbatasan dengan Selat Makassar. Kecamatan Binuang terdiri dari sembilan desa dan satu kelurahan diantaranya; Desa Batetangnga, Desa Tonyaman, Desa Rea, Desa Kuajang,Desa Mirring, Desa Mammi, Desa Paku, desa Amola, Desa Kaleok dan Kelurahan Amassangan. ${ }^{31}$

Jumlah Penduduk Kec. Binuang Dari Agustus 2016 terdiri dari 35.980 dengan stemasi 17.270 jiwa laki-laki dan 18.710 jiwa perempuan. Sehingga dengan jumlah ini, mununjukkan Kec. Binuang masuk dalam urutan kecamatan ke-empat terbayak penduduk di kabupaten Polewali Mandar, dari 16 kecamatan. Dari 16 kecamatan penduduk terbayak tersebut, urutan pertama diduduki oleh Kec. Polewali, Kec. Wonomulyo, Kec. Campalangiang dan Kec. Binuang. ${ }^{32}$

Sejarah masuknya Islam di Kecamatan Binuang, cukup penting untuk disampaikan sebab, daerah ini merupakan termasuk tempat pertama kali datangnya Islam di Kab. Polewali Mandar, bahkan di Provinsi Sulawesi Barat. Sekalipun ada beberapa pendapat lain mengklaim hal yang serupa. Namun bukti prasasti dan literatur membenarkan bahwa daerah inilah merupakan daerah awal datangnya ke-Islaman, yaitu adanya al-Qur'an tertua, Tasbih, bekas Mejid Tua Penanian, Makam Tosalama dan Lontar Kerajaan Balanipa yang kesemuanya telah membenarkannya.

Masyarakat suku Pattae dulunya memegang teguh kepercayaan anemisme dan dinamisme, yaitu menyembah pohon-pohon besar, batu dan percaya kepada roh-roh nenek moyang mereka dengan meletakkan jasat para keluarga mereka ke dalam lubang-lubang tebing batu. Namun setelah kedatangan ajaran Islam yang dibawa oleh Syekh Kamaluddin, kerajaan dan masyarakat mulai memeluk ajaran Islam dan meninggalkan kepercayaan nenek moyang mereka. Mereka kagum terhadap kromah Syekh Kamaluddin yang mampu shalat di pelapah pisang, berjalan di atas air, tidak menyentuh tanah ketika berjalan, dan dapat menyembuhkan orang sakit parah yang sulit lagi untuk disembuhkan.

Dari aspek pendidikan, Kec. Binuang memiliki tiga Pesanteren besar, empat MTs, satu sekolah kejuruan dan satu Pendidikan Tinggi Kejuraan. Ketiga pesanteren terkenal di daerah ini yaitu, Pondok Pesanteren DDI Kanang, Pondok Pesanteren Ar-Risalah Batetangnga, dan Pondok Pesantren Al-Wasilah Lemo.

Potensi sumber-sumber yang dimiliki Kecamatan Binuang terus dikembangkan untuk meningkatkan kesejahtraan penduduk. Terutama disektor

\footnotetext{
${ }^{31}$ Wikipedia, “Binuang”, t.d. https://id.wikipedia.org/wiki/Binuang,_Polewali_Mandar (03 Januari 2018).

${ }^{32}$ Pusat Statistik Kec. Binuang Kab. Polewali Mandar, Statistik Kependudukan, (18 Januari 2018).
} 
pertanian dengan produksi buah-buahan yang terkenal kualitas terbaik. Tanaman perkebunan yang produksinya sangat besar adalah kakao, padi, kopi, kelapa, dan cengkeh. Hal ini didukung oleh iklim yang sangat sesuai bagi perkembangan komoditi tersebut. Selain produksi pertanian Kecamatan Binuang juga memiliki potensi Perikanan, Peternakan, Pariwisata, Industri dan jasa.

Pariwisata misalnya terdapat beberapa objek wesata cukup terkenal diantaranya Wisata Buah, Permandian Biru, Salu Pajjan, Limbong Lopi, Rawa Bagun Pulau Karamasang, Limbong Lebok, Air Terjun Eran Batu, dll. Semua ada untuk memenuhi peningkatan kunjungan para wisatawan dari berbagai daerah maupun manca negara. Di bidang industri dan jasa, Kec. Binuang memiliki pelabuhan Silopo sebagai pelabulan barang dan sentral pengangkutan barang dan hasil pertanian dan perikanan daera setempat ke berbagai pulau di Indonesia. Semuanya ada untuk meningkatkan dan memenuhi pertumbuhan ekonomi Kec. Binuang.

\section{Konsep Hibah yang Berlaku pada Masyarakat Suku Pattae}

Umumnya masyarakat suku Pattae di Kec. Binuang hidup dengan budaya hibah orang tua kepada anaknya. Hibah ini telah tumbuh sejak dahulu, semenjak nenek moyang mereka mendiami wilayah ini hingga sampai sekarang. Mereka percaya bahwa kebiasaan ini perlu dipertahankan hingga sampai akhir kehidupan mereka dimasa akan datang. ${ }^{33}$

Masyarakat suku Pattae umumnya memiliki kebiasaan menyimpan hartanya dalam bentuk properti atau petakan tanah bukan dalam bentuk uang, baik uang itu disimpan dirumah maupun di bank-bank tertentu. Sehingga ketika ditelusuri di tengah masyarakat suku Pattae, mereka hampir tidak memiliki bayak uang namun kekayaan mereka telah dialihkan dalam bentuk tanah. Baik itu bentuk perkebunan kopi, kakao, cengkeh, durian, kapling rumah, empang, sawah, dll. Karena prinsip mereka, semakin kedepan uang pasti akan selalu bernilai turun akan tetapi tanah malah sebaliknya, akan selalu naik dan naik. Sehingga tanah yang mereka miliki nantinya, mereka gunakan sebagai penghidupan atau biaya sekolah anak-anak mereka dimasa akan datang ketika semuanya sudah sangat dibutuhkan. ${ }^{34}$

Berdasarkan kondisi masyarakat suku Pattae tersebut, maka wajar ketika mereka menggunakan hibah orang tua sebagai peralihan harta, sebab hibah ini nantinya akan dikategorikan sebagai warisan ketika orang tua mereka telah meninggal dunia. Hibah orang tua umumnya berupa sepetak tanah atau lebih,

\footnotetext{
${ }^{33}$ Sarianto A. Md. (39 Tahun), Kades Tappina, Wawancara, Tappina, 16 Desember 2017 dan Suleman (41 Tahun), dan Kades Mammi, Wawancara, Mammi, 10 Desember 2017.

${ }^{34}$ Abd. Muttalib D. (63 Tahun), Tomakaka Rappoang, Wawancara, Rappoang, 08 Desember 2017.
} 
yang diberikan kepada anak yang dianggap sudah dewasa. Namun kenyataannya masyarakat suku Pattae terlihat bahwa, hibah orang tua diberikan kepada anak ketika baru melangsungkan pernikahan sebagai tanah garapan untuk memenuhi kebutuhan hidup keluarga baru. ${ }^{35}$

Sistem hibah orang tua suku Pattae, sekalipun sudah ada sejak lama tetapi ada kemiripan dengan sistem pembagian hibah suku Toraja. Dan apabila dilihat dari persamaan adat istiadat maka mereka bayak kemiripan. "Mabongi"misalnya, yaitu suatu upacara adat kematian keluarga, yang hidup dan dipraktekan dalam adat istiadat suku Pattae. Tetapi ritual-ritual yang ada semua telah dirubah dengan bacaan-bacaan al-Qur'an sehingga tidak bertentangan dengan ajaran Islam, seperti yasinan dan menghatamkan al-Qur'an untuk si maiyit.

Upacara "mabongi" awalnya dilakukan dengan beberapa kali, mulai; "bongi 3", "bongi 7", dan seterusnya hingga "bongi 100" yaitu 100 hari dari kematian si maiyit. Sementara sanak saudara atau keluarga dekat berdatangan membawa sebagaian hartanya atau hasil panennya sebagai bantuan dan belahsukkawa atas meninggalnya si maiyit. Namun peraktik ini mulai berubah, yaitu dilakukan hanya beberapa kali saja atau cuma sekali saja selama 100 hari kematian si maiyit, karena sesuatu hal yang dianggap lebih baik.

Selain "ma bongi", ada juga yang mirip dengan budaya Toraja yang disebut "mana", sebuah harta peninggalan si maiyit yang hak kepemilikannya dimiliki secara kolektif oleh seluruh anak si maiyit yang ditinggalkan hingga sampai cucu-cicit. "Mana""sendiri, merupakan salah satu jenis harta warisan dari orang tua kepada anaknya di luar dari hibah yang diberikan sewaktu ia masih hidup. Namun perbedaan keduannya terletak pada waktu pemberian dan hak kepemilikan. ${ }^{36}$

"Mana" pada dasarnya merupakan sisa hibah orang tua dalam bentuk petakan tanah atau sepohon durian, setelah sebagian besar harta miliknya telah diberikan kepada anaknya. "Mana" merupakan harta dengan status kepemilikan bersama, tetapi hal ini berlaku setelah orang tua meninggal dunia. "Mana" terkadang memiliki fungsi sebagai ajang penyaluran hobby orang tua di masa senjanya, sehingga ia tetap memiliki aktivitas bercocok tanam atau berkebun, dan tidak memiliki kejenuhan yang hanya berdiam diri di rumah. Sebab kebutuhan dan tanggungan hidup sudah dijamin oleh anak-anaknya yang kini sudah berkeluarga. Sedangkan fungsi "mana" khususnya untuk anak yang ditinggalkan adalah sebagai ajang silaturahmi dari seluruh keturunan si maiyit, sebab dari anak si maiyit akan menceritakan kepada anak keturunannya bahwa ia memiliki "mana" (kebun durian orang tuanya) dan ia berhak kesana untuk

\footnotetext{
${ }^{35}$ Saraila (81 Tahun), Tokoh Adat, Wawancara, Ammassangan, 02 Desember 2017.

${ }^{36}$ Matta (71 Tahun), Tokoh Adat Batetangnga, Wawancara, Kanang, 04 Desember 2017.
} 
memungutnya, bersama dengan sepupu-sepupunya. Mulai dari sepupu sekali, sepupu dua kali, sepupu tiga kali dan seterusnya kebawah selama ia memiliki hubungan darah dari si maiyit.

Sebelum terjadinya pembagian hibah orang tua kepada anak, mereka terlebih dahulu menentukan waktu untuk membicarakan perkara ini, guna mengetahui bagian, luas, dan di mana petakan tanah tiap-tiap bagian anakyang didapatkan. Biasanya di tengah-tengah pembagian ini, mereka di perantarai oleh seorang imam, yaitu imam mesjid sebagai hakim hibah harta orang tua. Karena mayoritas masyarakat suku Pattae biasanya mengangkat seorang imam mesjid merupakan orang yang ditokohkan karena keturunan, berpendidikan, tahu persoalan agama dan tentunya dapat dipercaya berbuat adil dalam persoalan ini.Selain hakim hibah orang tua, mereka juga biasa memanggil beberapa saksi dalam kesepakatan antara orang tua dengan anak yang menerima hibah sebagai saksi mata apabila dikemudian hari ada persoalan yang ditimbulkan. ${ }^{37}$

Pembagian hibah orang tua kepada anak, dilakukan dengan cara berimbang melalui musyawarah antara orang tua dengan seluruh anak yang ada. Baik ia anak laki-laki maupun anak perempuan dengan diperantarai oleh hakim hibah atau imam yang di pilih oleh orang tua. Dari kesepakatan bersama melalui musyawarah antara anak dan orang tua tersebut, maka harta atau tanah milik orang tua kemudian dialihkan kepada anak. Biasanya di antara kesepakatan tersebut mereka menyiapkan sebuah surat tanda bukti kesepakatan sebagai prasyarat bahwa harta orang tua telah dialihkan sekaligus sebagai alat apabila terjadi sesuatu yang tidak diinginkan dikemudian hari. ${ }^{38}$

Adapun jumlah tanah bagian yang berimbang dimaksud sebelumnya, bukan berarti harus mesti sama, namun terkadang berbeda dari segi luas tetapi dari segi pemanfaatan sama. Misalnya anak pertama mendapatkan tanah dua hektar tetapi kurang subur, sementara anak kedua mendapatkan satu hektar tetapi tanahnya subur. Begitupun dengan kondisi lain yang agak sama, seperti anak pertama mendapatkan tanah dua hektar tetapi masih kosong akan tanaman yang bermanfaat seperti kakao, cengkeh, durian, kopi, dll. Sementara anak yang kedua mendapatkan tanah satu hektar tetapi tanahnya sudah penuh akan tanaman yang bermanfaat yang tinggal menunggu panen dan hasilnya. ${ }^{39}$

Ada juga ketika dalam musyawarah, terdapat anak yang memilih menyerahkan sebagian miliknya karena beralasan bahwa ia telah mengambil hak

${ }^{37}$ Abd. Muttalib D. (63 Tahun), Tomakaka Rappoang, Wawancara, Rappoang, 08 Desember 2017.

${ }^{38}$ Saraila (81 Tahun), Tokoh Adat Batetangnga, Wawancara, Ammassangan, 02 Desember 2017.

${ }^{39}$ Andi Nurlaela (50 Tahun), Isteri Raja Binuang, Wawancara, Ammassangan, 18 Desember 2017. 
hibahnya dari orang tua dengan biaya pendidikan yang ditempuh selama ini, sehingga jika dihitung-hitung ia sudah mendapatkan harta cukup bayak ketimbang saudara-saudara kandung lainnya. Inisiatif tersebut terkadang juga diambil oleh orang tua dan diberi penjelasan kepada yang bersangkutan sehingga mengerti dan memahami akan keputusan tersebut, mengapa ia mendapatkan petak tanah lebih sedikit ketimbang dengan anak yang lain.

Selain pembagian hibah orang tua dan "mana" dalam sistem pembagian harta orang tua suku Pattae sebelumnya, ada juga pembagian yang menarik untuk diuraikan di sini, yaitu rumah orang tua yang biasanya didapatkan oleh anak bungsu tetapi dalam hal ini, ia juga memiliki tanggungjawab lebih besar khususnya dalam memelihara dan menjaga orang tua dimasa senjanya, sekalipun anak-anak lain tidak bermaksud untuk melepas tanggungjawab sebagai anak. Namun anak-anak yang lain, juga tetap senantiasa mengunjungi dan memberikan perhatian sebaik mungkin baik dari kebutuhan jasmani maupun rohani orang tua. $^{40}$

Perlu dicatat disini dalam hal pemeliharaan orang tua, terkadang ada anak yang berkeinginan secara langsung untuk memelihara orang tua sendiri, sehingga orang tua tidak mesti bertempat tinggal atau dalam pemeliharaan anak si bungsu, tetapi terkadang dipelihara oleh anak sulung atau anak yang lain karena memilih untuk hidup dengan orang tua mereka. Begitipun dengan kondisi yang lain, orang tua yang langsung memilih tinggal bersama dengan anak yang paling disukai atau orang tua memilih tinggal di rumah anaknya dengan cara menggilir rumah anak, artinya orang tua terkadang dalam setahun ia tinggal di beberapa rumah anaknya secara bergantian.

Pembagian hibah orang tua suku Pattae juga perlu diketahui bahwa harta yang telah diberikan oleh orang tua kepada anaknya, dalam kondisi tertentu bisa ditarik atau diambil kembali oleh orang tua. Misalnya di kemudian hari ada anak yang telah diberikan hibah oleh orang tua, ternyata telah berbuat kasar atau berbuat semenah-menah kepada orang tuanya maka sebagai orang tua, ia berhak untuk mengambil kembali harta atau petakan tanah yang telah diberikan kepada anak yang bersangkutan. ${ }^{41}$

Budaya hibah orang tua suku Pattae di Kecamatan Binuang setelah menempuh perjalanan jauh, kini mulai ada pergeseran meski dari sekian bayaknya masyarakat suku Pattae ada sekitar kurang lebih 10\% kini menggunakan jasa Pengadilan Agama dalam memutuskan perkara peralihan harta orang tua dengan menggunakan hukum Islam secara sepenuhnya. Artinya mereka

\footnotetext{
Desember 2017.

${ }^{40}$ bd. Muttalib D. (63 Tahun), Tomakaka Rappoang, Wawancara, Rappoang, 08

${ }^{41}$ Hasan Dalle (72 Tahun), Tokoh Adat Batetangnga, Wawancara, Batetangnga, 15 Desember 2017.
} 
terlebih dahulu menunggu adanya kematian baru terjadi peralihan harta kekayaan. $^{42}$

Namun perlu dicatat, sekalipun ada masyarakat suku Pattae yang membagi harta orang tua mereka dengan menggunakan jasa Pengadilan Agama, namun mereka tetap menggunakan proferti dalam membagi harta mereka dan enggap menjual tanah milik orang tua hingga dalam bentuk uang atau emas sehingga dampaknya akan lebih memudahkan. Akan tetapi, mereka tetap membagi harta milik orang tua dalam bentuk perkebunan atau petakan tanah dengan estimasi $\frac{1}{2}$ yaitu, dua hektar untuk anak laki-laki dan satu hektar untuk anak perempuan. ${ }^{43}$

Kondisi seperti ini pada dasarnya tidak bisa memastikan apakah benar atau tidak mereka membagi harta milik orang tua mereka berdasarkan $\frac{x}{2}$ yaitu, bagian anak perempuan sama dengan dua bagian anak laki-laki, atau hanya secara angka tepat $\frac{x}{2}$ akan tetapi, angka ini tidak bisa menjadi acuan dalam menentukan tepat atau tidak pembagian $\frac{x}{2}$ itu, sebab setiap petakan tanah pasti memiliki nilai yang berbeda dan bukan ditentuakan dari luas suatu bagian petakan tanah anak tetapi harus dilihat juga dari sisi kesuburan tanah, letak geografis, tanaman yang ada dalam kebun, bentuk kebun, dll. Adapun bentuk kebun yang dimaksud yaitu, apakah dia datar atau terjal. Sementar dari sisi letak geografis yaitu, apakah dia di perkotaan, desa, atau pengunungan. Sebab hal ini sangat menentukan tingkat nilai mahal apa tidaknya suatu petakan tanah atau perkebunan tersebut. ${ }^{44}$

Adapun contoh pembagian hibah orang tua suku Pattae di Kecamatan Binuang yang sempat didapatkan yaitu;

Pertama, Keluarga Drs. Muhammad Natsir K., 59 (lima puluh sembilan) tahun, seorang Hakim Pengadilan Agama Kota Palu, dengan memiliki saudara yang terdiri dari 6 (enam) orang dengan rincian dua anak laki-laki dan empat anak perempuan. Menyampaikan bahwa dalam pembagian warisan keluarganya, mereka menggunakan sistem hibah dengan membagi rata harta kekayaan yang ada padanya melalui orang tua berdasarkan kesepakatan bersama para ahli waris. Mereka membagi harta kekayaan berupa kavling rumah yang kurang lebih

${ }^{42}$ Sarianto, A. Md. (39 Tahun), Kades Tappina, Wawancara, Tappina, 16 Desember 2017. Desember 2017

${ }^{43}$ H. Saraila (81 Tahun), Tokoh Adat Batetangnga, Wawancara, Ammassangan, 02 2017. 
120x15 m persegi dengan 20x15 m persegi tiap orangnya, baik itu laki-laki maupun perempuan. ${ }^{45}$

Kedua, Keluarga H. Abd. Hafid Tanca, 81 (delapan puluh satu) tahun, seorang tokoh masyarakat (Tomakaka Rea), dengan memiliki saudara 6 (enam) orang dengan rincian tiga anak laki-laki dan tiga anak perempuan. Ia membagi harta miliknya dengan sistem hibah orang tua. Luas tanah yang di bagi sekitar 900x600 m persegi berupa lahan perkebunan, dalam keterangannya ia membagi tanah miliknya menjadi enam bagian dengan bagian tiap anak 150x100 m persegi. Berdasarkan hasil musyawarah bersamah keputusan yang diambil selalu mengutamakan keadilan dan kesepakatan sehingga mereka merasa adil dan tidak merasa cumburu satu sama lain. ${ }^{46}$

\section{Kesimpulan}

Berdasarkan penjelasan di atas, maka dapat ditarik poin kesimpulan bahwa konsep hibah yang berlaku pada masyarakat Suku Pattae merupakan konsep hibah orang tua suku Pattae yang dilakukan dengan cara berimbang, yaitu membagi rata tanah milik orang tua kepada anak-anaknya melalui musyawara antara orang tua dengan seluruh anak yang ada. Baik ia anak laki-laki maupun anak perempuan dengan diperantarai oleh hakim hibah atau imam yang di pilih oleh orang tua sendiri. Biasanya di antara kesepakatan tersebut, mereka menyiapkan sebuah surat tanda bukti kesepakatan, sebagai prasyarat bahwa harta orang tua telah dialihkan sekaligus sebagai alat bukti apabila terjadi sesuatu yang tidak diinginkan dikemudian hari. Namun perlu dicatat, bahwa harta milik orang tua yang telah diberikan kepada anak sewaktu-waktu bisa ditarik kembali oleh orang tua apabila terjadi sesuatu yang tidak diinginkan seperti membunuh, menganiaya, menghina, dan lain-lain.

\footnotetext{
${ }^{45}$ Muhammad Natsir K. (59 Tahun), Hakim Pengadilan Agama Kota Palu, Wawancara, Kanang, 18 Juli 2018.

${ }^{46}$ Abd. Hafid Tanca (81 Tahun), Tomakaka Rea, Wawancara, Rea, 30 Juli 2018.
} 


\section{DAFTAR PUSTAKA}

Abd. Shomad. Hukum Islam: Penormaan Prinsip Syariah dalam Hukum Indonesia. Cet. I; Jakarta: Kencana Prenada Media Group, 2010.

al-Afriqìi, Muhammad bin Mukrim bin Manzhūr. Lisān al-'Arab, Juz I, Cet. I; Bāirut: Dār Shadir, t.th.

Gaffar, Abdul. Hibah dalam Perspektif Hadis Nabi: Kajian Tematik Terhadap Alternatif Pembagian Harta, Makassar: Alauddin University Press, 2013.

G. Kartasapoetra, R. G. Kartasapoetra. Pembahasna Hukum Benda Hipotek Hukum Waris, Cet. I; Jakarta: Bumi Aksara, 1990.

Gossip, "Sidang Rebutan Warisan Adi Firansyah", Indosiar.com, 13 April 2007. http://www.Indosiar.com (05 Nopember 2016).

Hadikusuma, Hilman. Hukum Waris Indonesia Menurut Perundangan, Hukum Adat, Hukum Agama Hindu dan Islam, Bandung: PT. Citra Adtya Bakti, 1991.

Hasbiyallah. Belajar Mudah Ilmu Waris Bandung: PT. Remaja Rosdakarya, 2007.

Hukum dan Kriminal, "Rebutan Warisan, Sebuah Makam Terpaksa Dibongkar", Metrotvnews.com, 28 September 2010. htt://www.metrotvnews.com (05 Nopember 2016).

Ibin, Dede. Hibah: Fungsi dan Kolerasinya dengan Kewarisan(t.d.)

al-Jurjānī, Ali bin Muhammad bin 'Ali. al-Ta'rīfat, Cet. I; Bāirut: Dār al-Kitāb al-'Arabì, $1405 \mathrm{H}$.

Jahar, Asep Saepudin dkk., Hukum Keluarga, Pidana dan Bisnis: Kajian Perundang-Undangan Indonesia, Fikih dan Hukum Internasional, Jakarta: Kencana Prenada Media Grup, 2013.

Muthiah, Aulia dan Novy Sri Pratiwi Hardani. Hukum Waris Islam: Cara Mudah dan Praktis Memahami dan Menghitung Warisan, Jakarta: PT. Buku Seru, 2015.

Moh. Muhibbin dan Abdul Wahid. Hukum Kewarisan Islam: Sebagai Pembaharuan Hukum Positif di Indonesia, Jakarta: Sinar Grafika 2011. 
as-Sa'di, Abdurrahman bin Nashir. Tafsir al-Karimirrahmān, Damaskus: Dār alFikr, t.th.

Suma, Muhammad Amin. Hukum Keluarga Islam di Dunia Islam, Cet. I; Jakarta: PT. Raja Garafindo Persada, 2004.

Supardin, Fikih Peradilan Agama di Indonesia: Rekonstruksi Materi Perkara Tertentu, Cet. I; Makassar, Alauddin University Press, 2014.

Syarifuddin, Amir. Hukum Kewarisan Islam, Jakarta: Kencana Prenada Media Group, 2012.

Tim Penyusun, Ensiklopedi Hukum Islam, Cet. V; Jakarta: Ichtiar Baru-Van Hoeve, 1997.

Pusat Statistik Kec. Binuang Kab. Polewali Mandar, Statistik Kependudukan, (18 Januari 2018).

Wadud, Amina. Qur'an and Women: Rereading the Sacread Text from a Women's Perspective, New York; Oxford University Press, 1999.

Wahid, Abdul dan Muhibbin, Hukum Kewarisan Islam, Jakarta: Sinar Grafika, 2009.

Wikipedia, "Binuang",

t.d. https://id.wikipedia.org/wiki/Binuang,_Polewali_Mandar (03 Januari 2018).

Yafie, Ali. Menggagas Fiqih Sosial: Dari Lingkungan Hidup, Asuransi, Hingga Ukhuwah, Cet. III; Bandung: Mizan, 1994.

Yasil, Suradi dkk. Naskah Awal Sejarah Polewali Mandar, Polewali Mandar: Pemeriantah Kab. Polewali Mandar-Dinas Perhubungan dan Informatika, t.th.

bin Zakariyā, Abū al-Husain Ahmad ibn Fāris. Mu'jam Maqāyis al-Lugah, Juz IV (Bäirut: Dār al-Fikr, 1423 H./ 2002 M.

Zuhayly, Wahbah. Al-Fiqh al-Islāmiy wa Adillatuhu, Damaskus: Dār al-Fikr, 1984), h. 453-454; dikutip dalam Asep Saepudin Jahar, dkk., Hukum Keluarga, Pidana dan Bisnis: Kajian Perundang-Undangan Indonesia, Fikih dan Hukum Internasional, Jakarta: Kencana Prenada Media Grup, 2013. 